\title{
Play: A Fundamental Equalizer for ESL Children
}

\section{Allan Silver}

The findings in the following article were gathered from a qualitative study designed to elicit the impact of providing play opportunities for children in the upper elementary school grades. One of the major themes that the researcher discerned was that play had a significant influence on ESL children by facilitating communication and socialization at the same time as it nurtured independence and self-esteem. This report, then, (a) rationalizes the use of play in classes for children 9-11 years of age, (b) defines play, and $(c)$ describes how play influences ESL children specifically.

\section{Introduction}

In this age of accountability, standardized testing, and outcomes-based education, it would seem that there is little room for play in an elementary school curriculum. Even during those years when child-centered education was being hailed as a model for schools, there was little if any time devoted to play, particularly by the end of grade 5 . The rationale for the exclusion of play has been discussed by Goffin (1989), who maintained that whereas early childhood programs provide play because they are grounded in child development principles as their guiding philosophy, elementary schools eschew the role of play because their overwhelming concern is with academic achievement. As she says,

the exclusion of play is a philosophical decision that reflects schools' emphasis on achievement. Conversely, the dominance of play and constructive activity in traditional early childhood classrooms reflect early childhood's respect for child development and the value of individuality, personal competence and learner activity. (p. 195)

As an elementary schoolteacher I have been well aware of my responsibilities for teaching my students the skills that would bring about academic success. At the same time, in my academic studies in applied psychology I have also been cognizant of the need for emotional and social development. Hence, in what became a dissertation leading to a doctorate of education, I undertook a research project to discover the results of providing play opportunities to a grade 5 class of 25 children who came from varied ethnic communities and for whom English was the primary language in only two homes. During the year in which this study was conducted, five of the 
students were withdrawn at some point during the day for ESL instruction. Three of these students had only recently arrived in Canada, whereas two others had been in Canada for several years but were deemed to be sufficiently behind in their acquisition of English that they were still registered in ESL classes. Of the 20 others approximately one quarter had attended ESL class at some point during their previous schooling. Once a week for a period of 45 to 60 minutes the students were given an opportunity to engage in a number of play activities such as painting, plasticine, the sandbox, drama, and art among others. The fact that play was being provided for a junior division class was in itself highly unusual. What made the study unique, however, was that the children themselves were responsible for much of the data collection insofar as they wrote reports about the play episodes. To a large extent it was my interpretation of the children's written documentation that provided the results of my research. For this reason my findings come much closer to revealing a truer version of events than previous studies of play, which have exclusively relied on the observations of adults.

Before I discuss how play directly influences ESL children, however, the reader must understand what is meant by the word play. Otherwise, one might easily become confused between the "spontaneous" play of this study and the "instrumental" play, which is usually associated with elementary school children.

\section{The Definition of Play}

To illustrate the meaning of play, consider an observer who on entering the classroom notices two girls painting on either side of an easel. The observer might conclude that these two children were either working or playing. The distinction between the two lies in large measure with "the context of the activity, not on the content of the activities themselves" (King, 1987, p. 160). For the purposes of this study it was determined that the child who is painting because it was her choice to paint and who decided on the theme of her painting was playing. On the other hand, the other child who is also painting would be considered to be working if she were pursuing an activity that had been designated by the teacher (as a follow-up to a novel study for example). In this case the child is not in control of the activity, and thus she is thought to be working. This difference is crucial to distinguishing work from play.

The following quotations from the children who were chosen as participants of this study and who were asked to define play also contribute to an understanding of what constitutes play:

"Activities are good because they are free."

"To have fun to get rid of pressure."

"You have fun naturally."

"Play means to do something in an active way." 
"I play basketball for fun because you will be under pressure if you just want to win."

The opinions expressed by these students together with those of various researchers (Saracho, 1991; Day, 1980; Rubin \& Pepler, 1982) led me to adopt the following criteria to define play:

1. intrinsic motivation;

2. concern with process rather than product;

3. control of the activity by the children themselves;

4. nonliterality;

5. freedom from externally imposed rules;

6. active participation.

The first characteristic is consistent with the children's belief that play is fun. If an activity is fun, a child will be intrinsically motivated to carry on with it, not because the play will result in an external reward either in the form of praise or grades, but simply for the sheer joy of doing it. For this reason King (1987) writes that "the criterion which gradually emerges as the single most important quality differentiating between work experiences and play experiences is that of pleasure" (p. 145). Day (1980) has also concluded that play is first and foremost an enjoyable activity that "is motivated by internal drives" (p.59) and occurring for its own sake.

Second, play is concerned with process rather than product. In almost every instance in school children are being evaluated on the basis of their performance on any particular assignment. During play, however, the participants need not concern themselves with the finished product because the only person they have to please is themselves. Whether the children continue with the play depends on the inner satisfaction they feel from actually doing the activity. Perhaps it is this characteristic of play that the students mean when they talk about "relax[ing] a little" and "having fun without pressure." In this respect we might again refer to the example of the two children who are painting. The child who is playing gains satisfaction from the activity itself and the sense of enjoyment she acquires from "doing" rather "achieving." In contrast, the child who is working is concerned with producing something that will earn her approval and praise from her teacher.

The third criterion, that the child is in control of the play, can also be understood with reference to the two children at the easel. A child at play, so Saracho (1991) maintains, engages in activities in which any goals that may be present are self-imposed and where the behavior of the player is spontaneous (p. 47). That is, a child at play is free to determine what kind of play she wants to engage in and the content of that play. Moreover, if she is not happy with her play, she is free to abandon it at any point. This spontaneous play is in contrast to the kind of instrumental play that King (1987) describes in her book School Play. 
King defines instrumental play as "activities organized by the teacher" but which older elementary school children label play if they enjoy participating. She maintains that "children enjoy instrumental play for many different reasons. These activities may permit physical activity; they may be undemanding and require little effort; they may permit social contact among children, encourage individual expression, or include interesting content" ( $\mathrm{p}$. 146). But she is also quite emphatic that this instrumental play is most definitely not the spontaneous, process-oriented, child-controlled play that was the subject of the study on which this article is based. In her words:

Although upper elementary school children call these activities play, there are numerous differences between instrumental play activities and the spontaneous play activities usually associated with children. Most importantly instrumental activities are not voluntary or self-directed, and they serve goals beyond the purposes of the participants. Teachers organize these activities so that playful elements are included, but the teacher maintains control of the situation and the playful elements are not permitted to obscure the academic messages. (p. 146)

The fourth characteristic, that play has a nonliteral quality about it, is most obviously witnessed in sociodramatic episodes. Sociodramatic play is most evident in preschool and kindergarten settings, but it is rarely discussed with respect to older elementary schoolchildren. One reason for this omission is that it has not been studied because 10- and 11-year-old children are rarely afforded the opportunity to engage in spontaneous pretend play that adults can observe. To explain this absence, Piaget (Singer, 1973) has contended that pretend play diminishes with older children. Nevertheless, in my study of play in my own grade 5 classroom, I have seen many instances where children engage in fantasy play with their peers. Indeed, my own observations contradict Piaget's claim and lend validity to Singer's (1973) findings that "children between the ages of 9 and 13 indicate a considerable continuing interest in make-believe activities and fantasy games" (p. 245). In this context it is noteworthy to point out a comment provided by one of the children involved in this study when she said "I would love to play with Barbies and dolls."

The fifth criterion, that play be free of externally imposed rules, is problematic for elementary schoolchildren because the "predominant form of children's play with the onset of concrete operations (i.e., ages 7-11) becomes the game with rules" (Rubin \& Pepler, 1982, p. 293). For the purposes of this study, however, and in accordance with Hutt's (Chazan, Laing, \& Harper, 1987) understanding of different kinds of play, I also include the use of games as a component of play. Researchers generally exclude games from a discussion of play because the former are associated with externally imposed rules. On the other hand, spontaneous play consists of children's 
freedom to control the activity and not be constrained by the limits imposed by a formal set of rules. My observations of children's play have led me to believe that it is possible to include games as a characteristic of play. The following example serves to illustrate the reason for this belief. In a game of pick-up-sticks I played with a student, the following exchange took place:

Student: You can whack the sticks now, Mr. S.

Teacher: What do you mean, I can whack the sticks?

Student: You know, you can hit the pile with one of your own after you've picked five up.

Teacher: No, I didn't know that.

Student: Oh yeah, that's a rule we made up. Everybody in the class knows it.

In this instance the children did not feel compelled to adhere to the rules of the game as stated in the instructions. Instead, they simply made up their own rule to suit their needs as they saw fit. Bettelheim (1972) has accounted for this behavior by saying that children "will move back and forth from games to play" until they have gained an adequate degree of maturity and self-esteem (p. 8).

Finally, play involves the active engagement of its participants. For however long the play lasts, the children will be engaged intellectually, physically, emotionally, and, depending on the activity, socially as well. For these reasons one child involved in the study said that "play means to do something in an active way." Henniger's (1987) views about play also support the belief that in play participants are actively involved. He states: "Play is a hands-on activity where children are learning by doing. Children in the play experience are not passive observers, but rather actively engaged in moving, manipulating, and exploring things in their world" (p. 170).

\section{The Influence of Play on ESL Children}

As stated above I relied to a large extent on the children's own written accounts of their play to conduct my research. With these children, in particular ESL students, who had difficulty communicating their thoughts in writing, I asked them to do what they could and to draw pictures of their activity if they wished. On those occasions when time permitted I would ask the children to express their thoughts about their sketch and then write down what they said. In addition, for those play episodes when an ESL child was socially engaged, I would corroborate what one child had said about her play by comparing it with the accounts of her playmates and with my own field notes. Through this constant comparison of the data I was able to ensure validity and reliability.

My findings indicated that play benefited ESL children in the following ways. First, play helped establish bonds of friendship among children who 
could not communicate well in English. It was noted that ESL children played in a solitary manner at building, painting, or doing cut and paste with junk materials. After varying lengths of time, during which the ESL children became accustomed to school and routines, they also became involved in games with children during the time designated for play. One child, Mehendan, who had arrived at the school from Afghanistan halfway through the school year, was observed to have played only by himself during the weekly play sessions (in accordance with ethical procedures for conducting research with children, I have adopted pseudonyms to ensure confidentiality). Mehendan was extremely shy and reticent, and if he did speak it was usually only one or two words at a time. Eventually, as recalled by a classmate in the following play anecdote, Mehendan finally began to interact with someone else during one of the play activities: "Yesterday I was working on the computer with my friend named Mehendan. We were playing Wheel of Fortune. Mehendan went first. He got one letter then after he didn't get it. When it was my turn I got a lot of letters."

In another instance, Peter remarked that he had fun playing Connect Four with Yusuf, a recent arrival from Ethiopia who could only communicate his participation in play through pictures ("I was playing with Yusuf; we had fun"). Through these two episodes we can see that play facilitates communication among students even when they do not speak the same language and helps foster friendships for those children.

Second, play allows those children who do not socialize with others because of language differences to function independently and feel successful. By reporting through the use of illustrations, Yusuf demonstrated that he used the play periods in constructive ways. Whether by building with Tinkertoy materials, practicing string tricks, or creating with junk, Yusuf was able to demonstrate independence during all of the play periods.

In my observations I noted that a boy named Paul, who had transferred from another school quite recently and who also had little facility with English, found a temporary niche (at the plasticine center) by building a varied assortment of monsters from Clayola. In fact Paul and I stored his characters in a special place in the classroom so that he could add to his collection weekly.

Another child, Arthur, a recent arrival from Pakistan, spent hours of focused, uninterrupted play as he assembled puzzles and made constructions from Lego materials. In all three cases the students would express their satisfaction with their accomplishments by showing me what they had done and smiling at my acknowledgment.

Third, only during these play occasions was the ESL child capable of being on an equal footing with the others in the class. Ordinarily, ESL students, particularly those who have only recently arrived in Canada, are extremely dependent on the other children in the class to demonstrate tasks 
and to help them with assignments. During classroom play, however, ESL students exhibited an independence and confidence that were not otherwise evident. In fact ESL children who were seen to be proficient at a particular play activity were often asked by others to help them with their activity. This was illustrated when Paul, who had been observed by the other children to be adept at making plasticine figures, was asked to contribute items of "food" to several girls who were dramatizing a skit about shopping. Similarly, Baldave, a student who was still receiving ESL instruction, was called on by a classmate to assist him in painting ("I do not know what to do but Peter said can you help to paint"). That ESL children are able to help others is especially significant because in almost every other instance in school it is the ESL child who is the recipient of assistance. Whenever there is an assignment involving reading, whether it be from a textbook or activity cards, ESL students are almost always teamed with a classmate who can convey the intent of the task to them. In some cases this dependence results in a sense of inferiority, a definite lack of confidence, and occasionally resentment. Therefore, the fact that play enabled ESL children to assert independence and express proficiency was instrumental in building self-esteem.

Last, play enables shy, insecure ESL children to gain confidence. Mary was a quiet Somalian child who had attended school in Canada for a year and a half but who had experienced so much difficulty in the acquisition of English and in her general academic performance that psychoeducational testing had been proposed. Mary was only able to print words (rather than use handwriting); her spelling was at an inventive stage (Mae an Kty an rBrt [Me and Katy and Robert]); her drawings were simplistic, undeveloped, and lacking in detail; and she would only speak in a whisper. Only on two occasions, both of which occurred during play sessions, did I hear Mary raise her voice to what could be described as a normal speaking level: once as she played a math game on the board with her friend Katie, another ESL child, and once when she played a math video game on the computer with the same friend.

\section{Summary}

The effects of play on ESL children were investigated as part of a research study that examined the use of play with children in the upper elementary school. In contrast to early childhood programs, which are based on child development principles, elementary schools have traditionally shunned the use of play because of their preoccupation with academic achievement. For the purposes of this research, play has been defined as an active, spontaneous, process-oriented, pleasurable activity that often has elements of make-believe and that can also include games, as long as the children are free to modify the rules as they see fit. Interpretation of the data concluded that there were a variety of clear benefits for all the children, and for ESL children 
specifically, with respect to building confidence and self-esteem. It was during play that these children were able to be independent and to demonstrate personal strengths that would not necessarily become apparent during regular school programs. For the short period while ESL children were engaged in these activities they were able to participate on a level playing field with their classmates.

\section{The Author}

Allan Silver graduated with a Doctorate in Education in applied psychology from the University of Toronto in 1998. He is presently an elementary school teacher with the Toronto School Board, a part-time instructor at Ryerson Polytechnic University, and a child psychotherapist.

\section{References}

Bettelheim, B. (1972). Play and education. School Review, 81, 1-13.

Chazan, M., Laing, A., \& Harper, G. (1987). Teaching five- to eight-year-olds. New York: Blackwell.

Day, B. (1980). Contemporary early childhood education programs and related controversial issues. In D.G. Range, J.R. Layton, \& D.L. Roubinek (Eds.), Aspects of early childhood education (pp. 39-86). New York: Academic Press.

Goffin, S. (1989). Developing a research agenda for early childhood education: What can be learned from the research on teaching? Early Childhood Research Quarterly, 4, 187-204.

Henniger, M. (1987). Learning mathematics and science through play. Childhood Education, 63, $167-171$.

King, N.R. (1987). Elementary school play: Theory and research. In J.H. Block \& N.R. King (Eds.), School play: A source book (pp. 143-165). New York: Garland.

Rubin, K.H., \& Pepler, D.J. (1982). Children's play: Piaget's views reconsidered. Contemporary Educational Psychology, 7, 289-299.

Saracho, O.N. (1991). Educational play in early childhood education. Early Childhood Development and Care, 66, 45-64.

Singer, J.L. (1973). The child's world of make-believe. New York: Academic Press. 